\title{
THE BEHAVIOURAL STUDY OF THE BUSH DOG (Speothos venaticus) IN CAPTIVITY WITH ENVIRONMENTAL ENRICHMENT
}

\author{
ESTUDO COMPORTAMENTAL DO CACHORRO-VINAGRE (Speothos venaticus) \\ EM CATIVEIRO COM ENRIQUECIMENTO AMBIENTAL
}
Thatijanne Santos Gonzaga de CARVALHO' ${ }^{1}$;árcio Gilberto ZANGERONIMO² Carlos Eduardo do Prado SAAD²; Vanessa Daniela Lázara de ASSIS ${ }^{3}$; Virgínia Mara Pereira RIBEIRO ${ }^{4}$

1. Doutoranda, Universidade Federal de Lavras - UFLA, Lavras, MG, Brasil; 2. Professor, Doutor, UFLA, Lavras, MG, Brasil. zangeronimo@dmv.ufla.br; 3. Doutoranda, Universidade Federal de Goiás-UFG, Goiânia, GO, Brasil; 4. Doutoranda, Universidade Federal de Minas Gerais, Belo Horizonte, MG, Brasil

\begin{abstract}
The bush dog (Speothos venaticus) is very rare animal species, whose maintenance and breeding in captivity can induce the expression of atypical behaviour. Information concerning environmental enrichment and assessment models of the behaviour of this species in the literature are insufficient. Therefore, a study was conducted in the Zoo-Botanic Foundation of Belo Horizonte, Minas Gerais, Brazil, to evaluate the behaviour of two male bush dogs kept in captivity with different types of environmental enrichment, in April-May 2012. Data collection was performed before, during and after the presence of the environmental enrichment, three times a week in the morning and afternoon on alternate days for ten minutes, with immediate recording of activity performed by the animal every minute. It was observed that the animals interacted with all three types of ENRI used, but showed a greater interest in ENRI-2. No stereotyped behaviour or aggressive behaviour was observed, suggesting satisfactory welfare conditions for the animals in all environments tested. We conclude that the enrichment protocols can be used to stimulate the natural behaviour of the species, aiding the well-being and quality of life in captivity.
\end{abstract}

KEYWORDS: Animal behaviour. Captive animals. Animal interaction. Welfare. Food enrichment.

\section{INTRODUCTION}

The bush dog (Speothos venaticus) is a canid, endemic to South America, occurring from Panama to Argentina, including a large part of Brazil. However, this animal is rare (BEISIEGEL; ZUERCHER, 2005; BEISIEGEL, 2009) and difficult to observe in the field (FUSCO-COSTA; INGBERMAN, 2013), and is thus little-studied. The species is considered vulnerable and is contained in Appendix I of the Convention on International Trade in Endangered Species of Wild Fauna and Flora in Endangered CITES (NOWAK, 1991). The main threats to the species are deforestation, fragmentation and the alteration of habitats, diseases transmitted by domestic animals and a decrease in their natural prey.

Bush dogs are diurnal animals, unlike other small canids (DEUSH, 1983), but are tolerant to different types of habitats (SILVEIRA et al., 1998) and have a rich repertoire of vocalizations (VILLA, 2001). This species is highly social, living in family groups containing two to twelve individuals in the presence of a single monogamous breeding pair for each group (KLEIMAN, 1972; BEISIEGEL; ZUERCHER, 2005). Observations indicate that these animals have semi-aquatic habits.
The maintenance and reproduction of some individuals in captivity is an alternative for the preservation of this species. However, captivity might induce the expression of artificial behaviours different to those observed naturally. Moreover, environmental enrichment and the adoption of appropriate management practices can contribute to the welfare of animals kept in captivity, because they stimulate natural behaviour.

Information concerning environmental enrichment and assessment models of the behaviour of this species are scarce. This study was conducted to study the behaviour of two individuals of captive bush dog subjected to different types of environmental enrichment in a municipal zoo in the city of Belo Horizonte-MG, Brazil.

\section{CONTENTS}

The research was conducted at the ZooBotanic Foundation of Belo Horizonte, Minas Gerais (FZB-BH), Brazil, during April and May 2012 and was approved by the Ethics Committee on Animal Use (CEUA) of the Federal University of Lavras, Minas Gerais, Brazil, under the number 045/13.

Two adult male bush dogs (Speothos venaticus), captive in the FZB-BH, under natural 
conditions of temperature and humidity, were used. The enclosure has an area of approximately $260 \mathrm{~m}^{2}$, with trees or lawn with tree trunks and a lake with free access to the animals, a house used for the daily supply of food and for shelter of the animals. The enclosure is completely surrounded by a screen fence that separates the animals from visitors and other animals.

Three environmental enrichments were used: ENRI-1; a trail of paprika leading to two objects, a leather-shelter adult bovine humerus impregnated with moist dog food and individually wrapped in paper bread or autoclaved camel pelage ENRI-2; a trail of basil leading to two pumpkins stuffed with basil and meat strategically positioned near the lake of the enclosure; ENRI-3; a trail of paprika leading to two cardboard boxes, each with the same leather-wrapped objects used in ENRI-1.

The behavioural parameters were evaluated on three occasions (before, during and after enrichment). The enrichment was always measured in the afternoon (15:00), and assessments were performed beforehand, in the morning $(10: 00 \mathrm{am})$ and in the morning of the next day (10:00 am). Each evaluation involved the observation of the animals during a period of $10 \mathrm{~min}$. Activities of the animals were recorded every minute in an ethogram established by the FZB-BH (Figure 1). We used a sampling technique scan (when the two animals were in the enclosure, but both identified for the assessment of individual behaviour) or a focal technique (when only one animal was in the enclosure), adapted from Altmann (1974). For the installation or removal of enrichment, the animals were trapped, and evaluations were performed after the animals were released. The data obtained for the animal behaviours were analysed by nonparametric Kruskal-Wallis tests using the statistical program Action 2.3, with $\alpha=0.10$.

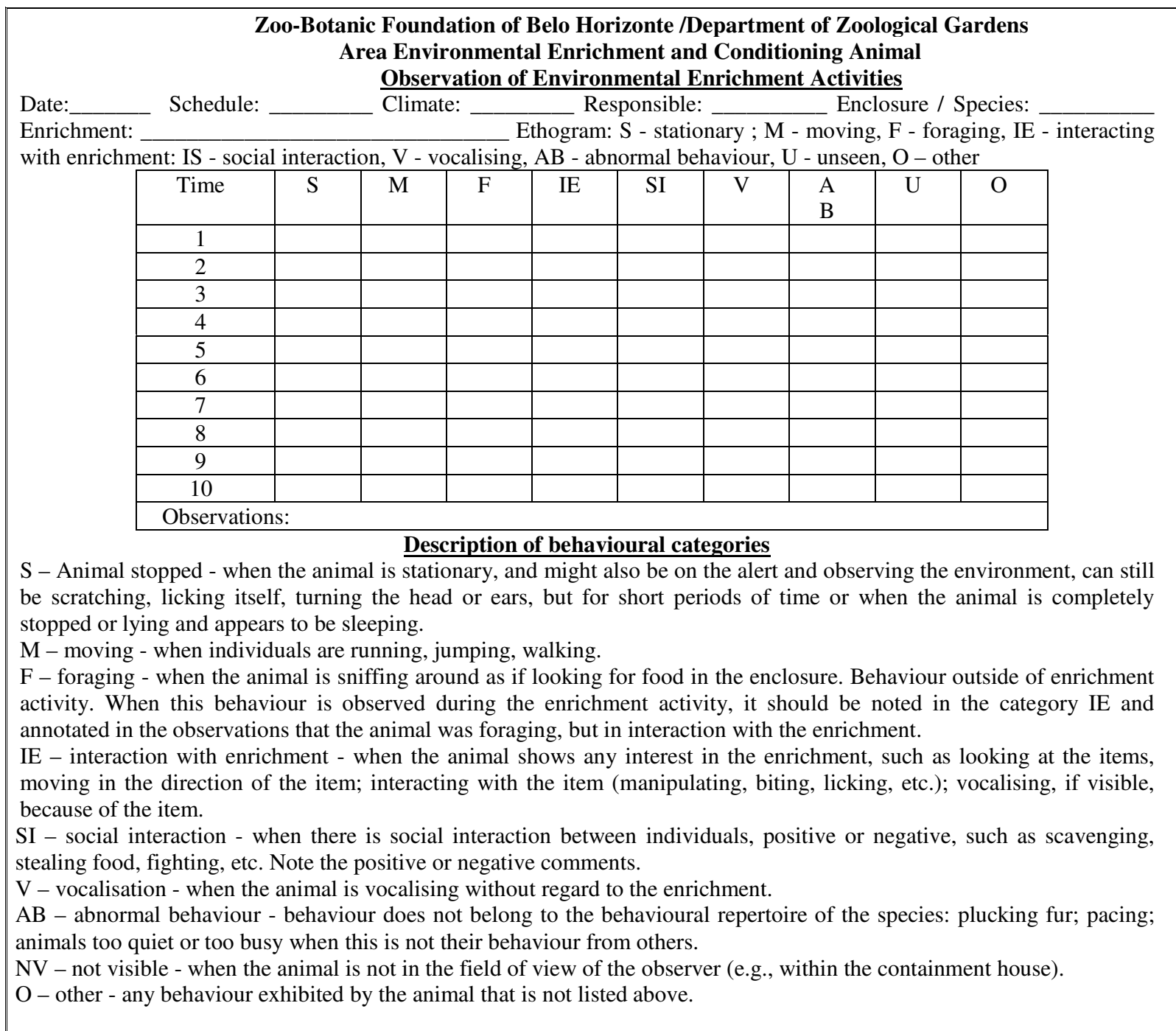

Figure 1. Ethogram established by the FZB-BH to evaluate the individual behavioural parameters of the bush $\operatorname{dog}$ (Speothos venaticus). 
Table 1 shows the behaviour shown by the animals during evaluation. The three types of enrichment used, reduced $(P<0.10)$ the rate of animal movement throughout the enclosure, during the placement of objects and after their removal. After enrichment, the animals were not visible to the observer most of the time.

Increased interest $(P=0.09)$ was demonstrated when ENRI-2 (trail of basil + pumpkins stuffed with basil and meat) was used. However, we also identified interactions of animals with ENRI-1 and ENRI-3. After installation of the enrichment, only the ENRI-1 (trail of paprika + adult bovine humerus wrapped in leather + autoclaved camel skin) caused the animals to remain longer at these locations (not visible to the observer).

Table 1. Number of events (reviewed every 10 minutes) of different bush dog (Speothos venaticus) behaviours assessed before, during and after the use of three types of environmental enrichments $(n=2)$.

\begin{tabular}{|c|c|c|c|c|c|}
\hline & Stationary & Moving & $\begin{array}{l}\text { Interacting with } \\
\text { enrichment }\end{array}$ & Not visible & Swimming \\
\hline \multicolumn{6}{|c|}{ - ENRI-1 - } \\
\hline Before & 2.0 & $8.0 \mathrm{a}$ & 0.0 & $0.0 \mathrm{a}$ & 0.0 \\
\hline During & 0.0 & $5.0 \mathrm{ab}$ & 3.0 & $2.0 \mathrm{ab}$ & 0.0 \\
\hline After & 2.5 & $1.5 \mathrm{~b}$ & 0.0 & $6.0 \mathrm{~b}$ & 0.0 \\
\hline$P$ value & 0.12 & 0.10 & 0.08 & 0.09 & - \\
\hline \multicolumn{6}{|c|}{ - ENRI-2 - } \\
\hline Before & 0.0 & $8.0 \mathrm{a}$ & $0.0 \mathrm{~b}$ & $2.0 \mathrm{ab}$ & 0.0 \\
\hline During & 0.0 & $2.0 \mathrm{ab}$ & $7.5 \mathrm{a}$ & $0.0 \mathrm{~b}$ & 0.5 \\
\hline After & 0.0 & $0.0 \mathrm{~b}$ & $0.0 \mathrm{~b}$ & $10.0 \mathrm{a}$ & 0.0 \\
\hline$P$ value & - & 0.08 & 0.09 & 0.08 & 0.38 \\
\hline \multicolumn{6}{|c|}{ - ENRI-3 - } \\
\hline Before & 0.0 & $7.0 \mathrm{a}$ & 0.0 & $3.0 \mathrm{ab}$ & 0.0 \\
\hline During & 2.0 & $5.0 \mathrm{ab}$ & 1.0 & $2.0 \mathrm{~b}$ & 0.0 \\
\hline After & 3.0 & $2.5 \mathrm{~b}$ & 0.0 & $4.5 \mathrm{a}$ & 0.0 \\
\hline$P$ value & 0.15 & 0.09 & 0.18 & 0.09 & - \\
\hline
\end{tabular}

ENRI-1: trail of paprika + objects wrapped in leather i.e., adult bovine humerus or autoclaved camel skin; ENRI-2: trail of basil + pumpkins stuffed with basil and meat; ENRI-3: trail of paprika + cardboard boxes + objects wrapped in leather i.e., adult bovine humerus or autoclaved camel skin; ${ }^{\mathrm{a}, \mathrm{b}}$ means followed by different letters in the column are significantly different using the KruskalWalis test $(P<0.10)$.

Other behaviours were also recorded, such as urinating along the enclosure or sheltering in the containment house, semi-aquatic behaviour (swimming in the lake of the enclosure) or attention to noise in neighbouring enclosures or to visitors to the zoo. Prior to enrichment, the animals urinated on the trunks scattered on the ground and in trees (mean 4.0 times/individual/evaluation in ENRI-1 and ENRI-2; 3.5 times/individual/evaluation in ENRI-3), moved throughout the enclosure (mean 8.0 times/individual/evaluation in ENRI-1 and ENRI-2; 7.0 times/individual/evaluation in ENRI-3) or hid in the containment house (no record in ENRI1 , a mean of $2.0 \mathrm{records} /$ individual/evaluation in ENRI-2; 3.0 records in ENRI-3). Following enrichment, the animals urinated again in the enclosure to mark territory, but at a lower frequency (mean 1.0 times/individual/evaluation in ENRI-1; no record in ENRI-2; 2.5 times/individual/evaluation in ENRI-3) and showed the behaviour of lying in the grass (mean 2.5 times/individual/evaluation in ENRI-1; no record in ENRI-2; 3.0 times/individual/evaluation in ENRI3 ). However, the behaviour of hiding inside the containment house was displayed more frequently than the others at this stage (mean of 6.0 records/individual/evaluation in ENRI-1; 10 records in ENRI-2; 4.5 records in ENRI-3); each unit represents one minute that the animal spent in the containment house.

The bush dog (Speothos venaticus) is a species of lesser-known neotropical canid (OLIVEIRA, 2009). Although some aspects of its behaviour have been studied in captivity, no study has evaluated the behaviour of these animals when faced with environmental enrichment in captivity 
with a scan sampling and adapted focal methodology.

To evaluate the behaviour of the animals, we used scan sampling and the focal methods of Altmann (1974), both of which consisted of observing the animals for ten minutes continuously at pre-determined intervals each minute, noting the behaviour shown, in an animal ethogram established by the FZB-BH. The scan technique was used when both animals were visible in the enclosure, however, both methods were used to assess individual behaviour, which differed from the original methodology, which evaluated the behaviour of the group as a whole and not the individual. The focal technique was used only when one individual was visible in the enclosure and differed from the original methodology by the fact that observations were performed every minute and not continuously during the $10 \mathrm{~min}$ to note the current time spent on each activity performed by the animal. These differences to the original methodology facilitated a more practical assessment of animal behaviour, generating notes in the ethogram and the final count rate for each behaviour performed by individuals.

Both animal individuals were well adapted to their venue and were familiar with human presence due to daily handling and the constant presence of visitors in the FZB-BH. The choice of enrichment studied was due to the availability of materials in the FZB-BH.

During the recording of behaviour, it was observed that on the day following enrichment, the animals showed a lower frequency of urination and stayed longer in the shelter. This type of behaviour appeared to indicate that enrichment diminished the interest of the animals in exploring the environment for at least the following day. The marking of territory with urine is typical behaviour of the bush dog and other canids (EISENBERG; KLEIMAN, 1972).

With respect to enrichments used, it is unclear whether the preference for ENRI-2 derived from its components, since the bush dog is carnivorous, with a diet consisting almost exclusively of animal meat (Van VALKENBURGH, 1991) or whether the fact that they have interdigital membranes and semi-aquatic habits (STRAHL et al., 1992) positively influenced the interaction with this enrichment, because the animals entered the lake from the enclosure and played with the pumpkin while swimming. In addition, other types of enrichment might have been disadvantaged by the fact that the bones of ox leather were commonly used by officials of the FZB-BH at least twice a week. The objects might have already been familiar to the animals, which led to a lower frequency of interaction with ENRI-1 and ENRI-3. However, regardless of the type of enrichment used, interaction with the enrichment was rapid, namely, the animals had no fear of approaching enrichments introduced into the enclosure used primarily with trails, and photographic records had already indicated that this species moves by trails (FUSCO-COSTA; INGBERMAN, 2013).

This study shows that the use of environmental enrichment aids the well-being and helps to maintain the quality of life in captivity, encouraging natural behaviour of the species through stimuli introduced into the enclosure, in addition to being an important tool for the preservation of this species, which is threatened with extinction.

From this study, it can be concluded that bush dog (Speothos venaticus) males showed no abnormal behaviour in enriched environments. The environment that most aroused curiosity of animals was a trail of basil leading to two pumpkins stuffed with basil and meat, strategically positioned near the lake precincts.

\section{ACKNOWLEDGEMENTS}

Zoo-Botanic Foundation of Belo Horizonte, Minas Gerais (FZB-BH), Brazil. At the FAPEMIG (PPM-00359-14) and CNPq (PQ 305478/2015-0) for financial support at researches.

RESUMO: O cachorro-do-mato-vinagre ou cachorro-vinagre (Speothos venaticus) é uma espécie animal bastante rara. Sua manutenção e reprodução em cativeiro pode induzir a expressão de comportamentos atípicos. Informações sobre enriquecimento ambiental e modelos de avaliação do comportamento dessa espécie são insuficientes na literatura. Sendo assim, um estudo foi realizado na Fundação Zoo-Botânica de Belo Horizonte, Minas Gerais, Brasil, para avaliar o comportamento de dois machos de cachorro vinagre mantidos em cativeiro com diferentes tipos de enriquecimento ambiental, entre os meses de abril a maio de 2012. A coleta dos dados foi realizada antes, durante e após a utilização do enriquecimento ambiental, três vezes por semana no período da manhã e da tarde em dias alternados, durante dez minutos, com registro instantâneo da atividade realizada pelo animal a cada minuto. Observou-se que os animais interagiram com os três tipos de enriquecimento utilizados, sendo demonstrado maior interesse pelo ENRI-2. Nenhum comportamento de estereotipia ou comportamento agressivo foi observado, sugerindo condições de bem-estar dos animais 
em todos os ambientes testados. Conclui-se que os protocolos de enriquecimento podem ser utilizados para estimular o comportamento natural da espécie, auxiliando no bem-estar e qualidade de vida em cativeiro.

PALAVRAS-CHAVE: Comportamento animal. Animais cativos. Interação animal. Bem-estar. Enriquecimento alimentar.

\section{REFERENCES}

ALTMANN, J. Observational study of behavior: sampling methods. Behaviour, v. 49, n. 3, p. $227-266,1974$. https://doi.org/10.1163/156853974X00534

BEISIEGEL, B. M.; ZUERCHER, G. L. Speothos venaticus. Mammalian Species, v. 783, p. 1-6, 2005. https://doi.org/10.1644/783.1

BEISIEGEL, B. M. First camera trap record of bush dogs in the state of São Paulo, Brazil. Canid News, v. 12 , p. 1-5, 2009.

DEUTSCH, L. A. An encounter between bush dog (Speothos venaticus) and paca (Agouti paca). Journal of Mammalogy, v. 64, n. 3, p. 532-533, 1983. https://doi.org/10.2307/1380378

EISENBERG, J. F.; KLEIMAN, D. G. Olfactory communication in mammal. Annual Review of Ecology and Systematics, v. 3, p. 1-32, 1972. https://doi.org/10.1146/annurev.es.03.110172.000245

FUSCO-COSTA, R.; INGBERMAN, B. Records of the bush dog Speothos venaticus in a continuous remnant of coastal Atlantic Forest in southern Brazil. Oryx, v. 47, p. 105-108, 2013.

https://doi.org/10.1017/S003060531200052X

KLEIMAN, D.G. Social behaviour of the maned wolf (Chrysocyon brachyurus) and Bush Dog (Speothos venaticus): A Study in Contrast. Journal of Mammalogy, v. 53, p. 791-806, 1972.

https://doi.org/10.2307/1379214

NOWAK, R. M. (Ed). Walker's mammals of the world. $5^{\text {a }}$ edição. Baltimore. The Johns Hopkins University Press, p. 634-635, 1991.

OLIVEIRA, T. G. Distribution, habitat utilization and conservation of the vulnerable bush dog Speothos venaticus in northern Brazil. Oryx, v. 43, p. 247-253, 2009. https://doi.org/10.1017/S0030605307002347

SILVEIRA, L.; JÁCOMO, A. T. A.; RODRIGUES, F. H. G. Bush dog (Speothos venaticus), in Emas National Park, Central Brazil. Mammalia, v. 62, p. 446-449, 1998.

STRAHL, S. D.; SILVA, J. L.; GOLDSTEIN, I. R. The bush dog (Speothos venaticus) in Venezuela. Mammalia, v. 56, p. 9-13, 1992. https://doi.org/10.1515/mamm.1992.56.1.9

VAN VALKENBURGH, B. Iterative evolution of hypercarnivory in canids (Mammalia: Carnivora): evolutionary interactions among sympatric predators. Paleobiology, v. 17, p. 340-362, 1991.

https://doi.org/10.1017/S0094837300010691 